\title{
Mask Etiquette amidst COVID-19 Crisis and Personal Protection Equipment Shortage
}

\begin{abstract}
The COVID-19 virus is transmitted through close contact between people, via droplets and possibly via airborne transmission. Wearing a mask is one of the recommended preventive measures that can reduce the transmission of COVID-19. But due to panic buying and increased demands, the health institutes are facing severe shortages of these PPEs. This article reviews the types of masks available, the feasibility of reusing them and the dos and don'ts of each suggested method.
\end{abstract}

Keywords: COVID-19, mask, personal protection equipment

\section{Introduction}

As of April 10, 2020, a total of 6412 cases and 199 deaths were confirmed by MOHFW in the country. ${ }^{[1]}$ Evidence suggests that the COVID-19 virus is transmitted through close contact between people and via droplets. Airborne transmission may occur during aerosol-generating procedures such as tracheal intubation, tracheotomy, cardiopulmonary resuscitation, and bronchoscopy; ${ }^{[2]}$ thus, the WHO recommends additional airborne precautions for such procedures. The incubation period for COVID-19 varies between 5-6 days and 14 days. In few of the reports, presymptomatic transmission has also been documented. ${ }^{[3-8]}$ This clearly indicates that people infected with COVID-19 could transmit the virus even before symptoms develop in them.

Wearing a mask is one of the recommended preventive measures that can reduce the transmission of COVID-19. However, the use of a mask alone is insufficient; optimum compliance with hand hygiene practices and social distancing is evenly critical to prevent human-to-human transmission of the virus. The fear created by COVID-19 has led to a panic buying spree by lay people and stocking masks including N95 at home. As a result, the health-care institutes are facing severe shortages of personal protection equipment.

This is an open access journal, and articles are distributed under the terms of the Creative Commons Attribution-NonCommercial-ShareAlike 4.0 License, which allows others to remix, tweak, and build upon the work non-commercially, as long as appropriate credit is given and the new creations are licensed under the identical terms.

For reprints contact: WKHLRPMedknow_reprints@wolterskluwer.com
The notion, "There is no scientific evidence for any beneficial effect for healthy people wearing masks" and "Medical masks should be reserved for health care workers," is partially correct. There is strong evidence to suggest that asymptomatic transmission occurs in the community. Countries such as Hong Kong, Singapore, South Korea, and Taiwan, who have a routine habit of wearing masks, have shown a flatter curve on the COVID-19 trajectory. ${ }^{[9,10]}$ Therefore, it would be rational to advise people in quarantine, vulnerable populations (older adults and those with underlying medical conditions), to wear face masks [Table 1].

N95 respirators are single-use devices, which are critical to prevent airborne infections in health care professionals (HCP), but shortages may occur during disease outbreaks. Hence, alternatives should be looked upon to mitigate these crisis situations.

\section{Alternatives to Single-Use N95 Respirators}

- Surgical masks were found to be equally efficacious as N95 masks in a hospital setting if they were worn regularly, with adherence to proper standards of wearing and removing them, and coupled with adequate hand hygiene measures. ${ }^{[13]}$ MOHFW ${ }^{[14]}$ has also advocated the use of surgical masks (a 3 layered mask which is disposable and fluid-resistant) by

- Health care workers

- If a person develops cough or fever

How to cite this article: Salunke G, Biswas SK, Bhat V. Mask etiquette amidst COVID-19 crisis and personal protection equipment shortage. Indian J Med Paediatr Oncol 2020;41:458-60.

\section{Gaurav Salunke ${ }^{1}$, S K Biswas", Vivek Bhat $^{2}$}

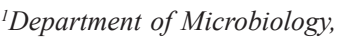
Tata Memorial Hospital, Homi Bhabha National Institute, Mumbai, Maharashtra, India, ${ }^{2}$ Department of Microbiology, ACTREC, Homi Bhabha National Institute, Mumbai, Maharashtra, India

Submitted: 17-Apr-2020

Revised: 01-Jun-2020

Accepted: 17-Jul-2020

Published: 29-Aug-2020

Address for correspondence:

Dr. Gaurav Salunke,

Department of Microbiology,

Tata Memorial Hospital, Homi

Bhabha National Institute,

Mumbai, Maharashtra, India.

E-mail:drgsalunke@yahoo.com

Access this article online

Website: www.ijmpo.org

DOI: 10.4103/ijmpo.ijmpo_165_20 Quick Response Code:

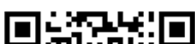

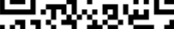
1.4 Brint

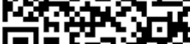
口intist 


\begin{tabular}{|c|c|c|c|c|}
\hline & Cloth Mask (3 laver) & Single-laver mask & Surgical/Medical Maska & Resnirator maskb \\
\hline Make & Cotton fiber & $\begin{array}{l}\text { Single layer of } \\
\text { nonwoven fabric or } \\
\text { wood pulp tissue paper }\end{array}$ & $\begin{array}{l}\text { Made up of three layers with } \\
\text { pleats }\end{array}$ & $\begin{array}{l}\text { Microfibers of polypropylene } \\
\text { layered on top of each other and } \\
\text { electrostatically charged }\end{array}$ \\
\hline $\begin{array}{l}\text { Effectiveness } \\
\text { against virus } \\
\text { particles }\end{array}$ & $50 \%-60 \%{ }^{[11]}$ & No & $\begin{array}{l}\text { Protects the patient }(75 \%-80 \%) \\
\text { but no self-protection }\end{array}$ & $\begin{array}{l}\text { Viruses }<0.3 \mu \mathrm{m} \text { microns are } \\
\text { filtered. Grades }{ }^{\mathrm{c}}\end{array}$ \\
\hline USE & Multiple & Single & Single & Single (difficult to breathe) \\
\hline Applications & $\begin{array}{l}\text { Asymptomatic General } \\
\text { Public. Not to be used by } \\
\text { any health care worker in a } \\
\text { hospital setting }\end{array}$ & Food industry & $\begin{array}{l}\mathrm{HCP} \text { at low risk or } \\
\text { symptomatic patient }\end{array}$ & $\begin{array}{l}\text { HCP who come in } \\
\text { close contact with the } \\
\text { COVID-19 patients. (high risk) }\end{array}$ \\
\hline Alternative & Surgical mask & Not available & N95, 3 layered cotton mask. & FFP2, N99, N100 and FFP3 ${ }^{d}$ \\
\hline \multirow[t]{4}{*}{ Reprocessing } & $\begin{array}{l}\text { Wash with Soap and Water, } \\
\text { dry and reuse }\end{array}$ & No quality evidence & No quality evidence & $\begin{array}{l}\text { Limited research but promising } \\
\text { results }^{[12]}\end{array}$ \\
\hline & & & & Hydrogen peroxide \\
\hline & & & & Moist Heat \\
\hline & & & & UV radiation lamp \\
\hline
\end{tabular}

${ }^{\mathrm{a}}$ Most surgical masks have three layers, an outer layers that repels fluids, a middle layer that acts as a barrier to microbes and an inner layer to absorb moisture. It does not offer a tight fit and there is enough space for the air to leak from all the sides of the mask, ${ }^{b} \mathrm{Respirator}$ Mask ${ }^{[13]}$ has an air filtering system that halts movement of microbes from entering inside the respiratory tract, and a tight fit, does not allow the air to leak from the sides into the nose and mouth, 'Grades of Respirator Masks: N stands for 'not oil resistant'. N is further divided into N95, N99, N100 depending on the filtration efficacy. N95 means that this mask can filter off at least $95 \%$ of particles which are $>0.3$ microns, while

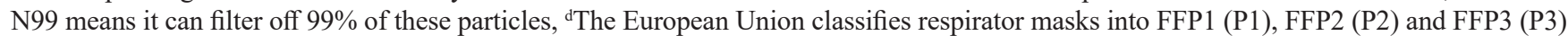
where FFP stands for Filtering Face Piece. N95 is roughly equivalent to FFP2 and N99 is roughly equivalent to FFP3 masks. N95 and other respirator masks are also available with a valve (not suitable for patients) and without a valve. HCP - Health care personnel; UV - Ultraviolet

- During a visit to a healthcare facility.

- When you have to care for an ill person

- Close family contacts of a suspect or a confirmed case/s undergoing home care.

- N95 - equivalent devices: Respirators not approved by NIOSH, but manufactured under regulatory standards, and in performance are equivalent to N95 masks, e.g., FP2 (Europe), KPN95 (China), or P2 (Australia)

- Reusable N95s and other respirators: Self-contained breathing apparatuses, elastomeric full-face N95s and N100s

- Expired N95 stocks: If stored properly, devices beyond their labeled shelf life usually retain adequate filter performance ${ }^{[15]}$

- N95s not certified for medical use: These include respirators certified by NIOSH but not certified by the Food and Drug Administration (FDA) (e.g., those for industrial use) and face covers made from conventional cloth or material used to make N95 filters.

\section{Reuse or Extended Use of N95 Masks}

Wearing an N95 respirator for hours at a time (i.e., extended wear) and reusing a respirator (i.e., donning and doffing between uses) are practices which can be adopted to ease shortages. With airflow rates consistent with breathing, theoretically, N95 protection should provide effective protection for prolonged hours, as long as the seal between respirator and face remains tight.
NIOSH and CDC guidelines do not include recommendations for reuse of single-use N95 respirators. Ideally, only the manufacturer of the respirators can provide reliable guidance on how to decontaminate their product. 3M, a manufacturer of N95 masks, also does not recommend the use of the following: ${ }^{[16,17]}$

- Ethylene oxide (associated with release of volatile organic compounds)

- Ionizing radiation (damages the performance of filters)

- High temperature in microwave (melts the metal components resulting in compromise of fit).

Several methods for single-use N95 disinfection have been recommended by third parties: ${ }^{[12,16]}$

1. Steam although nontoxic and easily penetrable to porous materials such as N95 filters, may damage polymer fibers in the filter and affect its performance

2. Chemicals could be toxic and incompatible with filter materials

3. Ultraviolet germicidal irradiation (UVGI) may not penetrate multilayered N95 masks, require enclosed space or shielded devices to protect users from ultraviolet (UV) exposure. UV equipment is equally expensive.

Although UVGI, hydrogen peroxide vapors, and moist heat have been most promising, their efficacy needs to be tested against different mask models.

Either reuse or extended use, both methods are associated with risk of mask to hand contamination, which can be decreased by: 
- Covering N95s with surgical masks or use of face shield to reduce surface contamination

- Avoid touching the inside or outside of the mask while using it

- Hand hygiene before putting the mask and after removing

- Discard respirators when visibly contaminated with potential pathogen sources like body fluids

- Store used N95s in designated areas between reuses. It should be stored in a designated area, located indoors where they cannot become crushed or distorted, in their original packaging or in a breathable container such as a paper bag, in a hazard-free environment (clean air) which is away from direct sunlight and acceptable humidity and temperature. ${ }^{[18]}$

Any guideline that you adopt should be on the basis of local scenario and the materials available. If given a choice, extended use of N95 masks is preferred over its reuse: ${ }^{[12,16,19]}$

- The mask to hand contamination risk from N95s is higher by repeated contact (frequent donning and doffing) as compared to by aerosol (spread by breathing through a used mask)

- Use of a surgical mask or a face shield over an N95s during extended use provides extra protection from body fluids

- Decontaminated masks can be worn for patient care activities but not while performing a procedure which generates aerosols ${ }^{[12]}$

- Mechanical problems like broken straps or poor sealing between the mask and the user's face appeared immediately after a few uses even in FDA-cleared N95 masks

- Adequate disinfection vs. loss of filter performance although encouraging; is still an understudy.

\section{When Left with No Alternatives, the Following Options May also Be Considered}

- Exclude high-risk HCP (old age, pregnancy) from COVID-19 from contact with known or suspected COVID-19 patients

- Convalescent HCP, i.e., Who have recovered from COVID-19 infection may be designated to take care of COVID-19 patients (but this has not yet been confirmed)

- Use only a face shield that covers the entire front, extends to the chin or below and covers the sides of the face

- In a poor resource setting, plan out a make shift isolation room (with the use of exhaust vents and high-speed table fans that provides a high-ventilation-rate and a zone under negative pressure.

\section{Financial support and sponsorship}

Nil.

\section{Conflicts of interest}

There are no conflicts of interest.

\section{References}

1. Home Ministry of Health and Family Welfare GOI. Available from: http://www.mohfw.govin. [Last retrieved on 2020 Apr 10].

2. Tran K, Cimon K, Severn M, Pessoa-Silva CL, Conly J. Aerosol generating procedures and risk of transmission of acute respiratory infections to healthcare workers: A systematic review. PLoS One 2012;7:e35797.

3. Yu P, Zhu J, Zhang Z, Han Y. A familial cluster of infection associated with the 2019 novel coronavirus indicating possible person-to-person transmission during the incubation period. J Infect Dis 2020;221:1757-61.

4. Huang R, Xia J, Chen Y, Shan C, Wu C. A family cluster of SARS-CoV-2 infection involving 11 patients in Nanjing. China Lancet Infect Dis 2020. doi: 10.1016/ S14733099(20)30147-X.

5. Pan X, Chen D, Xia Y, Wu X, Li T, Ou X, et al. Asymptomatic cases in a family cluster with SARS-CoV-2 infection. Lancet Infect Dis 2020;20:410-1.

6. Tong ZD, Tang A, Li KF, Li P, Wang HL, Yi JP, et al. Potential Presymptomatic Transmission of SARS-CoV-2, Zhejiang Province, China, 2020. Emerg Infect Dis 2020;26:1052-4.

7. Wei W, Li Z, Chiew C, Yong S, Toh M, Lee V. Presymptomatic Transmission of SARS-CoV-2 - Singapore, January 23-March 16, 2020. MMWR. Morbidity and Mortality Weekly Report 2020;69:411-5.

8. Kimball A, Hatfield KM, Arons M, James A, Taylor J, Spicer K, et al. Asymptomatic and presymptomatic SARS-CoV-2 infections in residents of a long-term care skilled nursing facility - King county, Washington, March 2020. MMWR 2020;6:377-81.

9. Ganyani T, Kremer C, Chen D, Torneri A, Faes C, Wallinga J, et al. Estimating the generation interval for coronavirus disease (COVID-19) based on symptom onset data, March 2020. Euro Surveill 2020;25:pii: 2000257.

10. Liu X, Zhang S. COVID-19: Face masks and human-to-human transmission. Influenza Other Respir Viruses 2020. Ahead of Print.

11. Davies A, Thompson K, Giri K, Kafatos G, Walker J, Bennett A. Testing the efficacy of homemade masks: Would they protect in an influenza pandemic? Dis Med Public Health Preparedness 2013;7:413-8.

12. Available from: https://www.cdc.gov/coronavirus/2019-ncov/ hcp/ppe-strategy/decontamination-reuse-respirators.html. [Last accessed 2020 Jul 02].

13. Long $\mathrm{Y}, \mathrm{Hu} \mathrm{T}$, Liu $\mathrm{L}$, Chen $\mathrm{R}$, Guo $\mathrm{Q}$, Yang $\mathrm{L}$, et al. Effectiveness of N95 respirators versus surgical masks against influenza: A systematic review and meta-analysis. J Evid Based Med 2020;13:93-101.

14. Available from: https://www.mohfw.gov.in/pdf/Guidelineson rationaluseofPersonalProtectiveEquipment.pdf. [Last accessed 2020 Jul 02].

15. Available from: https://www.cdc.gov/coronavirus/2019-ncov/hcp/ release-stockpiled-N95.html. [Last accessed $2020 \mathrm{Jul}$ 02].

16. Available from: https://www.elsevier.com/_data/assets/pdf file/0006/997863/COVID-ECRI-N95-Respirators_2020-03.pd. [Last accessed $2020 \mathrm{Jul}$ 02].

17. Available from: https:/multimedia.3m.com $/ \mathrm{mws} /$ media/18248690/decontamination-methods-for-3m-n95respirators-technical-bulletin.pd. [Last accessed $2020 \mathrm{Jul}$ 02].

18. Available from: https://multimedia. $3 \mathrm{~m} . \mathrm{com} / \mathrm{mws} / \mathrm{media} /$ $1730965 \mathrm{O} /$ tips-on-storage-and-use-of-3m-filtering-facepiecerespirators.pdf. [Last accessed $2020 \mathrm{Jul}$ 02].

19. Available from: https://www.cdc.gov/niosh/topics/hcwcontrols/ recommendedguidanceextuse.html. [Last accessed $2020 \mathrm{Jul}$ 02]. 